\title{
Wages versus Fringe Benefits in the Large-scale Manufacturing Sector of Pakistan
}

\author{
ZAFAR MAHMOOD and MOHAMMAD ALI QASIM
}

\section{INTRODUCTION}

In pursuit of its labour welfare policy and to provide protection against certain contingencies, the government plays a crucial role in introducing and encouraging the payment of fringe benefits. ${ }^{1}$ The proportion of total remunerations which make up fringe benefits is influenced by preferential treatment under income tax laws. ${ }^{2}$ For example, social security and employee's old-age benefits schemes are financed, respectively, through contributions by the employers at 7 percent and 5 percent of the wages of secured workers. These expenses are reduced if an employer pays more in the form of fringe benefits than wages. Some other gains, including reduction in labour turnover, increase in labour productivity and creation of a favourable public image of the enterprise encourage employers to offer fringe benefits rather than wages. On the other hand, interests of labour unions are to protect or to get an increase in their total pay package. Workers will prefer fringe benefits if, with their introduction, net income rises and savings are made by group purchases of some benefits. Thus, these benefits affect decision of labour supply and demand, and enhance welfare.

These tripartite interests have raised many interesting issues such as: (i) what accounts for the growth and size of fringe benefits? (ii) how well fringe benefits substitute for wage benefits in a worker's preference patterns? (iii)does collective bargaining alter the composition of remunerations? (iv) and in what way does the

Zafar Mahmood and Mohammad Ali Qasim are, respectively, Senior Research Economist and Staff Economist at the Pakistan Institute of Development Economics, Islamabad.

Authors' Note: We are thankful to the discussant of this paper for making useful comments.

${ }^{1}$ Workers receive remunerations for the services they render to any enterprise. The composition of remunerations is much more elaborate than just the direct wage. In addition to wages workers also receive a wide range of indirect remunerations-known as fringe benefits-including, payments in kind (e.g. food, transport, housing, etc.); social security benefits (e.g. old-age, maternity, and employment injury payments, life insurance, health care, severance pay, etc.); pay for the time not actually worked (e.g. paid holidays, cash grants, etc.); bonus and profit-sharing.

${ }^{2}$ Note, while some benefits are taxable, they are not so at lower income levels or benefits may be valued at lower amounts than it would cost the employee to acquire them directly. 
growth in fringe benefits affects the economy? See Rice (1966) and Woodbury (1983). Due to limitations in data availability, in this paper we only analyse the composition, growth and size of fringe benefits, and their consequences for the economy.

\section{DATA}

Data about fringe benefits cannot be obtained from a single source. For this study we have utilised two data sources: ${ }^{3}$ Census of Manufacturing Industries (CMI) conducted by the Federal Bureau of Statistics for the period 1970-71 to 1987-88 and "Terms and Conditions on Employment in Pakistan, 1992", a survey conducted jointly by Friedrich Ebert Stiftung and Employer's Federation of Pakistan (FES/EFP).

The CMI is the most comprehensive of all the surveys which report on fringe benefits. CMI reports on the aggregates of wages, 'other cash benefits', and 'noncash benefits'. ${ }^{4}$ CMI data suffer from the problem of non-response and is periodical. For the years in which CMI was not conducted we have interpolated the data series. ${ }^{5}$ Although, CMI contains data on value-added and non-wage components of total remunerations yet it does not report their disaggregation.

The FES/EFP survey covers the manufacturing and services sectors and reports both statutory and non-statutory fringe benefits. This survey, however, does not contain data regarding total remunerations and other economic variables. Another limitation of this survey is its coverage, it contains only 180 private or public limited manufacturing units and is available only for one year. Besides CMI and FES/EFP surveys, for the regression analysis we have utilised the PIDE Econometric Model data.

\section{EMPIRICAL ANALYSIS}

Employers offer numerous fringe benefits in varying combinations. We report the percentage of firms paying statutory and non-statutory fringe benefits in Table 1. Due to obvious reasons statutory benefits, whether of currently spendable or deferred payments type, are reported to have the maximum availability. Ironically

3"Enquiry on Labour Welfare" a survey conducted by the Federal Bureau of Statistics also reports on fringe benefits, but we did not use this survey because (i) this survey only covers statutory fringe benefits, (ii) no information on total remunerations and value-added is reported and (iii) it is seriously affected from under-reporting and non-response.

${ }^{4}$ 'Other cash benefits' includes; conveyance, house rent, compensatory and other such allowances, bonus, social security contribution and provident fund and 'non-cash benefits' includes; rent free accommodation, medical and transport facilities, and cheap/free consumer goods.

${ }^{5}$ The years in which CMI was not conducted are, 1971-72 to 1974-75, 1979-80 and 1981-82. 


\section{Table 1}

Fringe Benefits Available to Workers

Percentage of Firms Reporting

Fringe Benefits

Payments of Fringe Benefits

Leave Encashment

Earned

Casual

54.4

Leave Non-statutory

Education

Recreation

Statutory Obligation

Workers Compensation

61.7

EOAB

97.8

Social Security

78.9

Children Education

91.1

Welfare Fund

61.1

Group Insurance

89.4

Profit Sharing

48.3

Housing

32.8

Transport

59.4

Uniforms and Protective Equipments

92.8

Medical Non-statutory

64.2

Canteen

Recreation

Loans

House Building/Land Purchase

Motor Cycle/Bicycle/Marriage

Cash Grant

Marriage

Death

Eid

Bonuses

Production

Customary

Exgratia

\section{Deferred Benefits}

Gratuity

Provident Fund

Pension

Retiring Benefits

Source: Based on FES/EFP (1992).

Note: A caveat about this table must be mentioned that the availability of fringe benefits in a firm does not mean that these are available to all the employed workers and that the amount of non-statutory fringe benefits given to workers vary from firm to firm. 
a good number of firms managed to avoid these payments. This avoidance was certainly made possible with the connivance of government functionaries.

Despite the fact that encashment of leaves helps in minimising absenteeism, only 33.9 percent of firms encash earned leaves and 54.4 percent of them encash casual leaves. Similarly, even though provision of food on work saves working time only 13.9 percent firms provide canteen facilities.

It appears from Table 1 that employers give more weight to turnover of workers, that is why in order to attract workers to remain attached with the firms 73.9 percent of them provide 'good service award' and 58.3 percent of them provide motorcycle/bicycle loans to their tenured workers. On the other hand, to create a good public image firms reportedly provide cash grants and retiring benefits on the basis of need rather than on the basis of contribution to output. However, these non-statutory benefits are relatively less important.

Growth in fringe benefits can be decomposed into two components: (i) due to increase in total remunerations and (ii) due to increase in the share of fringe benefits in total remunerations.

Table 2 reveals that during the period 1970-71 to 1987-88, total real remunerations of all workers grew at a rate of 4.82 percent per annum. The biggest annual growth to the tune of 5.5 percent in total remunerations was realised by production workers, while total remunerations for non-production workers grew at an annual rate of 2.41 percent.

Next we analyse the growth in shares of various components of total remunerations. It may be noted from Table 3 that although the share of wages has declined at the rate of 1.31 percent per annum during 1970-71 to 1987-88 period, yet they still account for about 67 percent of total remunerations. Interestingly, the fall in the share of wages was gradual instead of a large jump at the time of the introduction of labour reforms in 1972. This was partly due to the reason that many of the benefits were already enjoyed by the workers and the labour reforms only revised their limits/ceilings. ${ }^{6}$ Another reason for the slow growth of fringe benefits was that with an understanding of the usefulness of such benefits trade unions and labour groups gradually started favouring them, particularly voluntary fringe benefits.

${ }^{6}$ Fringe benefits available before 1972 were social security (1967), including programmes such as medical care, sickness, maternity, work injury, pension and death benefits, and profit-sharing (Companies Profits Act, 1968). While in the labour reforms of 1972 worker's children education was introduced and employee's old-age benefits scheme was introduced in 1976. 
Table 2

Total Real Remunerations of Workers in the

Large-scale Manufacturing Industries

(In Rupees)

\begin{tabular}{lrcc}
\hline Year & $\begin{array}{c}\text { All } \\
\text { Workers }\end{array}$ & $\begin{array}{c}\text { Production } \\
\text { Workers }\end{array}$ & $\begin{array}{c}\text { Non-production } \\
\text { Workers }\end{array}$ \\
\hline $1970-71$ & 9012 & 7713 & 14937 \\
$1971-72$ & 9900 & 8535 & 15702 \\
$1972-73$ & 10415 & 9242 & 16371 \\
$1973-74$ & 9274 & 8466 & 14383 \\
$1974-75$ & 8500 & 7889 & 13043 \\
$1975-76$ & 8877 & 8077 & 11428 \\
$1976-77$ & 10368 & 9527 & 13612 \\
$1977-78$ & 11137 & 10304 & 14348 \\
$1978-79$ & 11990 & 10955 & 15864 \\
$1979-80$ & 12300 & 11430 & 15484 \\
$1980-81$ & 12463 & 11780 & 14892 \\
$1981-82$ & 12940 & 12379 & 15195 \\
$1982-83$ & 14450 & 13832 & 16456 \\
$1983-84$ & 15499 & 15032 & 16619 \\
$1984-85$ & 15998 & 19708 & 11056 \\
$1985-86$ & 17411 & 16188 & 21412 \\
$1986-87$ & 19066 & 17406 & 24750 \\
$1987-88$ & 20414 & 18317 & 27749 \\
Trend Growth & & & $2.41 \%$ \\
Rate & $4.82 \%$ & $5.5 \%$ & \\
\hline
\end{tabular}

Source: Based on Census of Manufacturing Industries (Various Issues).

Another interesting point that emerges from Table 3 is that in 1970-71 the share of wages in their total remunerations was higher for the production workers (i.e., 87.6 percent) compared to 79.7 percent for non-production workers, a trend that prevailed throughout the 1970s. But in the 1980s this trend was reversed, in 1988 the share of wages of production workers became 66.94 percent as compared to 67.26 percent for non-production workers. This is contrary to the general impression that fringe benefits are more important for non-production workers as compared to production workers. 
Table 3

Percentage Shares of Wages, Other Cash Benefits and Non-cash Benefits for all Workers, Production and Non-production Workers

\begin{tabular}{|c|c|c|c|c|c|c|c|c|c|}
\hline \multirow[b]{2}{*}{ Year } & \multicolumn{3}{|c|}{ All Workers } & \multicolumn{3}{|c|}{ Production Workers } & \multicolumn{3}{|c|}{ Non-production Workers } \\
\hline & $\begin{array}{l}\text { Wages/ } \\
\text { Salaries }\end{array}$ & $\begin{array}{c}\text { Other } \\
\text { Cash } \\
\text { Benefits }\end{array}$ & $\begin{array}{c}\text { Non- } \\
\text { cash } \\
\text { Benefits }\end{array}$ & $\begin{array}{l}\text { Wages/ } \\
\text { Salaries }\end{array}$ & $\begin{array}{c}\text { Other } \\
\text { Cash } \\
\text { Benefits }\end{array}$ & $\begin{array}{c}\text { Non- } \\
\text { cash } \\
\text { Benefits }\end{array}$ & $\begin{array}{l}\text { Wages/ } \\
\text { Salaries }\end{array}$ & $\begin{array}{c}\text { Other } \\
\text { Cash } \\
\text { Benefits }\end{array}$ & $\begin{array}{c}\text { Non- } \\
\text { cash } \\
\text { Benefits }\end{array}$ \\
\hline $1970-71$ & 85.10 & 11.58 & 3.32 & 87.60 & 10.21 & 2.19 & 79.70 & 14.55 & 5.75 \\
\hline $1971-72$ & 83.25 & 12.94 & 3.81 & 85.54 & 11.75 & 2.71 & 78.36 & 15.40 & 6.06 \\
\hline $1972-73$ & 81.21 & 14.42 & 4.37 & 83.61 & 13.03 & 3.36 & 76.91 & 16.30 & 6.43 \\
\hline $1973-74$ & 78.99 & 16.02 & 4.99 & 81.70 & 14.28 & 4.02 & 75.75 & 17.06 & 6.76 \\
\hline $1974-75$ & 76.58 & 17.74 & 5.68 & 80.15 & 15.13 & 4.72 & 74.37 & 17.97 & 7.13 \\
\hline $1975-76$ & 73.97 & 19.58 & 6.45 & 74.31 & 19.70 & 5.99 & 73.21 & 19.32 & 7.47 \\
\hline $1976-77$ & 72.86 & 19.35 & 7.80 & 73.41 & 18.92 & 7.67 & 71.39 & 20.48 & 8.13 \\
\hline 1977.78 & 71.86 & 20.10 & 8.03 & 72.09 & 19.96 & 7.95 & 71.27 & 20.48 & 8.25 \\
\hline $1978-79$ & 71.39 & 19.81 & 8.80 & 72.55 & 18.63 & 8.82 & 69.09 & 22.09 & 8.82 \\
\hline $1979-80$ & 70.56 & 20.42 & 9.02 & 71.26 & 19.63 & 9.11 & 69.10 & 22.10 & 8.81 \\
\hline $1980-81$ & 69.71 & 21.05 & 9.24 & 69.94 & 20.66 & 9.41 & 69.10 & 22.11 & 8.79 \\
\hline $1981-82$ & 70.30 & 20.56 & 9.13 & 70.41 & 20.40 & 9.20 & 69.83 & 21.23 & 8.91 \\
\hline $1982-83$ & 70.89 & 20.08 & 9.03 & 70.88 & 20.14 & 8.99 & 70.57 & 20.39 & 9.04 \\
\hline $1983-84$ & 69.38 & 21.02 & 9.60 & 69.61 & 20.70 & 9.70 & 68.79 & 21.86 & 9.36 \\
\hline $1984-85$ & 69.28 & 22.78 & 7.94 & 69.21 & 22.70 & 8.09 & 69.44 & 22.97 & 7.59 \\
\hline $1985-86$ & 67.32 & 23.11 & 9.58 & 66.03 & 23.84 & 10.13 & 70.32 & 21.38 & 8.30 \\
\hline $1986-87$ & 66.78 & 22.97 & 10.25 & 66.05 & 23.29 & 10.66 & 68.43 & 22.24 & 9.33 \\
\hline $1987-88$ & 67.04 & 23.61 & 9.35 & 66.94 & 23.65 & 9.42 & 67.26 & 23.53 & 9.21 \\
\hline \multicolumn{10}{|c|}{ Trend Growth } \\
\hline Rate & -1.31 & 3.39 & 5.79 & -1.60 & 4.20 & 8.10 & -0.85 & 2.38 & 2.50 \\
\hline
\end{tabular}

Source : Based on Census of Manufacturing Industries (Various Issues).

Despite the fact that cash wages provide more flexibility than payments in kind and that their total pay, in general, does not exceed the basic allowance allowed as straight deduction for the total income to arrive at the taxable income, production workers prefer fringe benefits. This behaviour can be attributed to rising costs of housing, medical, items available at fair-price shops, etc. and to the fact that house rent and medical allowances are below the taxable limits. Similarly, preference of non-production workers for higher fringe benefits can both be attributed to inflation and to the fact that full tax is not levied ${ }^{7}$ on these benefits. Out of the non-wage benefits, non-cash benefits have grown, proportionately at a higher rate (5.79 percent per annum) compared to other cash benefits (3.39 percent per annum)

${ }^{7}$ For details see Government of Pakistan (1993). 
see Table 3. This is, however, true, particularly, for the production workers who realised 8.1 percent per annum increase in the 'non-cash benefits' compared to 4.20 percent per annum increase in 'other cash benefits'. On the other hand, non-production workers realised nearly similar growth for both 'other cash benefits' and non-cash benefits, i.e. 2.38 percent and 2.50 percent, respectively. Despite the higher growth of non-cash benefits, other cash benefits still account for 23.6 percent of share in total remunerations compared to 9.35 percent share of non-cash benefits. This distribution has emerged as most of the work force receives house rent allowance (a part of other cash benefits) rather than rent-free company housing (a part of non-cash benefits). The same holds for conveyance allowance as compared with the provision of a transport facility.

Having shown that both the share of fringe benefits and total remunerations have increased, it can easily be established that the absolute level of these benefits has also increased. To confirm this we report in Table 4 the growth of various components of total remunerations for all workers, and production and non-production workers.

Out of the components of total remunerations, 'non-cash benefits' grew at the rate of 10.61 percent per annum followed by 'other cash benefits' ( 8.21 percent) and wages (3.51 percent) (see Table 4). Total remunerations for production workers grew at 5.5 percent per annum compared with 2.41 percent per annum for nonproduction workers. 'Other cash benefits' and 'non-cash benefits' for production workers, respectively, grew at an annual rate of 9.73 percent and 13.56 percent. On the other hand, the growth rates for non-production workers were 4.78 percent and 4.84 percent.

\section{Table 4}

Growth Rates of Various Components of Real Remunerations (1970-71-1987-88)

\begin{tabular}{lccc}
\hline \multicolumn{1}{c}{ Compensation } & $\begin{array}{c}\text { All } \\
\text { Workers }\end{array}$ & $\begin{array}{c}\text { Production } \\
\text { Workers }\end{array}$ & $\begin{array}{c}\text { Non-production } \\
\text { Workers }\end{array}$ \\
\hline Wages/Salaries & 3.51 & 3.90 & 1.56 \\
Other Cash Benefits & 8.21 & 9.73 & 4.78 \\
Non-cash Benefits & 10.61 & 13.56 & 4.84 \\
Total Non-wage Benefits & 8.85 & 10.68 & 4.80 \\
Total Remuneration & 4.82 & 5.50 & 2.41 \\
\hline
\end{tabular}

Source: Census of Manufacturing Industries (Various Issues). 
Having portrayed fringe benefits as an important component of total remunerations in the manufacturing sector, we now show the way the growth in these benefits affect productivity, inflation,employment, etc.

If these benefits are considered as a substitute for wages then there is no reason to associate increases in them with higher costs and inflation. ${ }^{8}$ But there is a possibility that the growth of fringe benefits increase labour costs, which in turn leads to an increase in total remunerations and price, and possibly a loss of competitiveness and/or employment. To test the hypothesis that increases in fringe benefits would lead to increases in inflation we use the following regression model: ${ }^{9}$

$$
\begin{gathered}
\operatorname{Ln} P_{8}=\underset{(1.67)}{0.220}+\underset{(13.04)}{0.23} \operatorname{Ln} P_{m}-\underset{(0.67)}{0.051} \operatorname{Ln} C_{s}+\underset{(12.16)}{0.560 \operatorname{Ln} P_{s}(-1)}+\underset{(2.98)}{0.062 \operatorname{Ln} F B} \\
R^{2}=0.99 ; \quad F=18964.5 ; \quad D W=2.61
\end{gathered}
$$

where, $P_{g}=$ Implicit GNP deflator; $P_{m}=$ Import price index; $C_{s}=$ Ratio of value-added by commodity producing sectors to value-added by services sectors; $F B=$ Fringe benefits.

Here we find a significant and positive impact of fringe benefits on inflation. since in Pakistan a part of these benefits are statutory, therefore, one cannot rule out this relationship, that is employer's do shift their rising fringe costs on in higher prices.

For a given pay package, if workers appreciate company's welfarism when they are paid fringe benefits as compared to direct wages it is expected that as a result of joint satisfaction and team work labour productivity will increase. To test this hypothesis we used the following regression model:

$$
\begin{gathered}
\operatorname{Ln} Y / L=\underset{(4.95)}{-14.48}+\underset{(2.36)}{0.870} \operatorname{Ln}(K / L)+\underset{(5.18)}{0.590 \operatorname{Ln} F B}+\underset{(3.37)}{0.099 \operatorname{Ln}\left(L_{n p} / L_{p}\right)} \\
R^{2}=0.99 ; \quad F=158.98 ; \quad D W=1.53
\end{gathered}
$$

where, $Y / L=$ Labour productivity; $K / L=$ Capital-intensity; $L_{n p} / L_{p}=$ Skill-intensity.

${ }^{8}$ Higher statutory fringes are not a substitute of direct wage increase but constitute a tax on a firm which can be shifted by raising its sales prices. Non-statutory fringes are less likely to have inflationary effects because of the difficulty in passing the costs on in higher prices. On the other hand, statutory fringes levied on all firms affect every competitor in the same way and hence it may not be too difficult for all firms to raise their prices in the same degree.

We also tried the share of fringes in total pay package in all the regressions and found quite similar results [see, conference paper] 
The above estimated regression shows that the relationship between fringe benefits and labour productivity in the manufacturing sector is positive and statistically significant. However, the magnitude of elasticity induces firms to involve themselves in other ways to mitigate the effect of the rising cost of fringe benefits, even though the growth in these benefits helps in increasing productivity.

Fringe benefits that affect costs and productivity may directly or indirectly affect employment. For example, the costs of recruitment and training which once made do not recur during the worker's period of employment, but would have to be incurred again if a new worker is to be recruited. So if fixed costs are substantial the firm will try to keep turnover low. In such a situation if a firm requires additional workers the firm will first go for overtime rather than recruiting additional workers. So the firm will employ a somewhat smaller labour force than they would have done if fixed labour costs had been low. On the other hand, if fringe benefits bring about an increase in productivity this induces firms to go for a bigger workforce. To test whether these benefits are positively associated with employment we put forward the following regression model:

$$
\begin{aligned}
& \operatorname{Ln} L=\begin{array}{c}
16.94 \\
(12.1)
\end{array} \quad+\underset{(3.58)}{0.217 \operatorname{Ln} B F}-\underset{(3.22)}{0.600} \operatorname{Ln}(K / L) \\
& R^{2}=0.49 ; \quad F=6.41 ; \quad D W=2.38
\end{aligned}
$$

where, $L=$ employment in the manufacturing sector.

The above estimated regression shows a positive and statistically significant relationship between fringe benefits and labour employment in the manufacturing sector. The positive sign shows that increased worker's welfarism do matter in increasing labour productivity which in turn induces firms to go for a bigger employment level so as to maximise their profits.

\section{CONCLUSIONS AND POLICY IMPLICATIONS}

The results of this study show that fringe benefits have become an important part of total remunerations. Fringe benefits account for 33 percent of total remunerations. When fringe benefits make up a significant part of workers' total income, they should be taken into account while deciding about the public policy to be followed, for instance, in the establishment of minimum wages and other forms of wage regulations.

High growth of fringe benefits speaks of tripartite interests in these benefits rather than direct wages. However, it may be noted that rising inflation is imposing 
a heavy burden on firms committed to substantial payments in kind and they may like to reverse their on-going policies on such benefits. But at the same time these benefits make it cheaper to work employees 'overtime' than to hire new employees. Thus employers have to make careful decisions regarding the composition of the pay package.

The analysis of the effects of fringe benefits on the economy shows that fringe benefits affect productivity, employment and inflation positively and significantly. Based on these results we recommend both to the government as well as to employers to go in favour of fringe benefits, especially voluntary benefits, as they help in improving both productivity and employment in the economy. However, policy-makers have to keep an eye on their affect on inflation. Encouragement of voluntary (non-statutory) benefits not only helps in achieving economic growth but macro-economic stability as well.

Finally, in order to attempt many other questions raised in the introduction, this study calls for an improvement in the data base. In particular, CMI should also report on the disaggregates, preferably by the classification of statutory benefits vs non-statutory benefits; other cash benefits vs non-cash benefits.

\section{REFERENCES}

Pakistan, Government of (1993) CBR Year Book, 1991-92. Islamabad: Revenue Division, Central Board of Revenue.

Rice, R. (1966) Skill, Earnings, and the Growth of Wage Supplements. American Economic Review Proceedings May: 56.

Woodbury, S. A. (1989) Substitution between Wage and Non-wage Benefits. American Economic Review March: 37-1. 


\section{Comments on}

\section{"Wages versus Fringe Benefits in the Large-scale \\ Manufacturing Sector of Pakistan"}

Let me begin by commending the authors on focussing their attention on an area which of recent has generated intense debate and analysis in the developed world; especially in the context of trade competitiveness of Japan vis à vis USA and Western Europe and the role played by fringe benefits in keeping the overall cost of production down and the corresponding international competitiveness of Japan high.

\section{General Comments}

After reading through the paper the first thing that became quite apparent to the reader is that, perhaps, the time and the space constraints imposed by the management of this conference have forced the authors to present only a cursory analysis of the issues regarding the topic. However, as a "fact-finding" study, the paper remains an interesting piece of research. Nevertheless, I personally would have preferred to see some more diagnosis of the situation, specifically the role of government policy in determining the level of fringe benefits vis $a$ vis the wages. Similarly, after reaching the end of the paper one could not help but having the feeling that not enough was said on the policy implication of the analyses. A little more focus on these two areas would make the paper extremely useful.

\section{Specific Comments}

1. The authors present a number of factors that could, and possibly have, influenced the relatively higher growth of non-wage remunerations (fringe benefits) of the workers. However, for some odd reason they ignored the most important one i.e. the reduction in cost to the employer in terms of providing the workers with services which he can purchase at a much lower cost because of "bulk purchase" than it would cost the workers to acquire individually. This alone is cited as the most important factor in keeping the cost of production relatively low in Japan as compared to the Western world. 
2. I also believe that some statements of the authors are too general and need qualifications. For example, the authors state that "[Since] total remunerations are what ultimately matters to the workers in making their labour supply decisions,..."; this statement is obviously valid if one is talking about the cash remunerations only. This quite apparently is not the case as the CMI data includes the monetary value of the benefits paid in kind. In this situation, when some of the benefits are paid in kind, the statement is true only if the valuation is done from beneficiary's perspective i.e. cash and kind benefits evaluated at marginal rate of substitution of fringe benefits for cash wages. As CMI data is based on imputed value of these non-cash remunerations, total valuation of remunerations as given in the CMI, in all probability, would be different from beneficiary's valuation of the package. For instance, a remuneration package of Rs 5,000 in cash and no rent-free housing will be totally different for the workers than the package with no cash and Rs 5,000 worth of rent-free housing.

3. Similarly, the statement that "Non-statutory fringes are less likely to have inflationary effects because of the difficulty in passing the costs on in higher prices" appears to be a little odd. One fails to understand that once the benefits are paid what distinguishes statutory and non-statutory benefits from the view point of production cost. One can definitely make out a case for cash benefits versus non-cash benefits as far as impact on inflation is concerned, but not so for statutory vs non-statutory benefits. I, for one, had considerable problem in conceptualising non-statutory benefits being less inflationary than statutory benefits.

4. Although I agree with authors explanation of the smooth decline in the share of wages over time, however, part of this "smoothness" could very well be because of the data problems. CMI data were not available for the years 1971-72, 1972-73, 1973-74, 1979-80 and 1981-82 and were interpolated by the authors; thereby "smoothing out" most of the discreteness, if any, in the data as the missing data correspond to the years (or years close to the years) when important policy changes took place.

5. I admit that I am not an expert on econometrics. Nevertheless, I believe that some of the regressions presented in the paper are not well specified. For example, the independent use of fringe benefits variable as a ratio of total remunerations in the inflation regression is questionable. Given that the estimated coefficient of the variable is positive, this implies:

(a) That if both the numerator and denominator both increase (decrease) but 
the former increasing (decreasing) faster than the latter, the prices would increase (decrease). Or

(b) That if fringe benefits increase (decrease) with total remunerations remaining constant i.e. a switch from (to) wages to (from) fringe benefits, the price level would increase (decrease). Or

(c) If fringe benefits remain constant while wages (i.e. total remunerations) increase (decrease) then the price level would decrease (increase).

It is, therefore, difficult to explain the positive relationship between the price level and fringe benefits, especially in the situation (b) and (c) above.

Although the equation is an aggregate price equation and the possibility of any variable being zero in any year is extremely remote. However, on theoretical grounds, the invalidity of the specification is obvious by visualising the fringe benefits in any given year to be zero (although an extremely remote but a definite possibility). The equation, the way it is specified, would imply that the general price level would also be zero-an impossibility. It would have been better to include the fringe benefit variable in absolute terms, or added the total remuneration variable as a separate independent variable in the regression. Also, some other functional form than the double-log should have been tried.

6. The interpretation of the positive coefficient of the fringe benefit variable in the productivity regression is less than obvious and the authors made no attempt to present any argument for the inclusion of FBs variable in the equation or for the positive coefficient of the variable. I cannot understand why would the labour productivity increase if fringe benefits increase; other things, including total remunerations (i.e. switch from wages to fringe benefits) remaining the same. I could not give myself any explanation of this revealed preference of workers for fringe benefits vis à vis the wages.

7. Similarly, given that the fringe benefit variable is used as a proportion of total remunerations, it is not surprising that FBs variable in the employment equation comes out insignificant. After all why would the employer or employee prefer one rupee of fringe benefits over one rupee of wages; especially if one considers the insignificant coefficient of the FBs variable in the tax equation.

12/B-1,

Eshya Mujahid-Mukhtar

Satellite Town,

Rawalpindi. 